CZASOPISMO INŻYNIERII LĄDOWEJ, ŚRODOWISKA I ARCHITEKTURY JOURNAL OF CIVIL ENGINEERING, ENVIRONMENT AND ARCHITECTURE

JCEEA, t. XXXIV, z. 64 (2/II/17), kwiecień-czerwiec 2017, s. 63-81, DOI: 10.7862/rb.2017.82

\author{
Roman CIEŚLIŃSKI ${ }^{1}$
}

Michał PRZYBYLSKI ${ }^{2}$

\title{
OCENA HYDROCHEMICZNA KLECSI EKOLOGICZNEJ NA JEZIORZE DRUZNO I RZECE WĄSKIEJ W 2014 ROKU
}

\begin{abstract}
Celem pracy jest ocena hydrochemiczna wpływu zanieczyszczeń, jakie wprowadzono w dniach 19-20.05. 2014 roku do rzeki Wąskiej, a następnie Jeziora Druzno i ustalenie czy można ten incydent traktować jak klęskę ekologiczną. Z Jeziora Druzno wyłowionych zostało bowiem w tym czasie około 2 ton martwych ryb, w tym również gatunków będących pod ochroną, a także drobnych organizmów wodnych takich jak ślimaki i małże. Pozostaje do wyjaśnienia czy przyczyną tego stanu rzeczy był wypływ zanieczyszczeń z zakładu „Sery” ICC Pasłęk. Dlatego przeprowadzono kwerendę materiałów źródłowych oraz badania terenowe i laboratoryjne. W 2015 roku dokonano poboru próbek wody z rzeki Wąskiej i Jeziora Druzno, które następnie poddano analizie pod kątem określenia stężeń takich wskaźników jak azot azotanowy(III), azot azotanowy(V), azot amonowy. Wykonano również modelowanie transportu zanieczyszczeń na rzece Wąskiej przy użyciu programu HEC-RAS. W efekcie ustalono, że zanieczyszczenia jakie dostały się poprzez rzekę Brzezinkę do Wąskiej miały charakter lokalny i nie było podstaw do uznania tego wydarzenia jako klęski ekologicznej tego regionu.
\end{abstract}

Słowa kluczowe: zanieczyszczenie, jakość, amoniak, transport

\section{Wstęp}

Woda jest jednym z najważniejszych elementów zaspokajających potrzeby człowieka. Dlatego w jego interesie jest to, aby dbać o nią pod względem czystości i przydatności. Szczególny wpływ na zanieczyszczenie wody ma działalność gospodarcza człowieka, jak i wiele innych uwarunkowań antropogenicznych i naturalnych, które w ekstremalnych sytuacjach prowadzą do klęsk ekologicznych.

\footnotetext{
${ }^{1}$ Autor do korespondencji / corresponding author: Roman Cieśliński, Uniwersytet Gdański, Katedra Hydrologii, ul. Bażyńskiego 4, 80-952 Gdańsk, tel. 585236529, georc@univ.gda.pl

${ }^{2}$ Michał Przybylski, Biuro Projektów Środowiskowych w Gdańsku, ul. Heweliusza 11, 80-890 Gdańsk, tel. 514326411, oddzialywanie@gmail.com
} 
Klęski ekologiczne to zjawiska, które powodują zmiany w środowisku w danym obszarze dla danych populacji czy gatunków w taki sposób, że brak jest możliwości egzystencji $\mathrm{w}$ miejscu ich bytowania. Klęski ekologiczne zachodzą w różnych sytuacjach, choć główną ich przyczyną są zmiany abiotyczne środowiska wynikające choćby $\mathrm{z}$ dopływu opadów atmosferycznych, zmian temperatury, czy presji drapieżników. Wpływ na pojawienie się katastrofy ekologicznej mają także zanieczyszczenia środowiska, wycinka lasów, zmiany klimatyczne, czy zakwaszenie wód. Według mediów i instytucji związanych z ochroną środowiska jedną z największych klęsk ekologicznych obszaru Żuław Wiślanych jest ta, która miała miejsce w maju 2014 roku i dotyczyła jeziora Druzno i rzeki Wąskiej. W niniejszej pracy dokonana będzie próba ustalenia, czy rzeczywiście była to klęska ekologiczna, czy raczej incydentalne zanieczyszczenie wód.

Celem głównym pracy jest ocena hydrochemiczna wpływu zanieczyszczeń, jakie wprowadzono w dniach 19-20.05.2014 roku do rzeki Wąskiej w trakcie awarii w zakładzie „Sery” ICC Pasłęk na warunki jakościowe i środowiskowe rzeki oraz pośrednio jeziora Druzno. Celem dodatkowym pracy jest ustalenie rzeczywistych wartości obliczonych zanieczyszczeń w stosunku do tych podawanych przez instytucje państwowe. Również ważne jest przedstawienie procesu transportu zanieczyszczeń rozpuszczonych w wodach rzeki Wąskiej. W związku z tym, że głównym zanieczyszczeniem był azot amonowy, w pracy ograniczono się do jego oceny, a także udziału innych zjawisk w procesie oczyszczania rzeki, które mają miejsce $\mathrm{w}$ trakcie jego przemian w środowisku wodnym. W ramach uzupełnienia prześledzono zmiany stężeń azotu azotanowego(III) i azotu azotanowego(V). Ponadto w dalszej części pracy przedstawiono przeliczenia oraz dane dotyczące innych form wyrażania azotu amonowego jak: jon amonowy $\mathrm{NH}_{4}{ }^{+}$, niejonowa forma amoniaku $\mathrm{NH}_{3}$, cząsteczkowa forma jonów amonowych i niejonowych form amoniaku $\mathrm{NH}_{4}{ }^{+}+\mathrm{NH}_{3}$. Jako główny obiekt badań wybrano rzekę Wąską, gdyż ona jako podstawowy odbiornik zanieczyszczeń jest bardziej narażona na presję zanieczyszczeń.

\section{Metody badań}

Główne prace polegały na kwerendzie materiałów źródłowych uzyskiwanych z instytucji państwowych m.in. Instytutu Meteorologii i Gospodarki Wodnej, Regionalnego Zarządu Gospodarki Wodnej i Wojewódzkiego Inspektoratu Ochrony Środowiska, a także z pozycji literatury przedmiotu, które dotyczyły obszaru badań, jak i informacji merytorycznych dotyczących pracy. Wykonano również prace kameralne polegające na opracowaniu danych i ich analizie. Analizie poddane zostały nie tylko dane dotyczące jakości wody, ale także dane hydrologiczne i hydrauliczne, które mają istotny wpływ na odbiór zanieczyszczeń i ich przemieszczanie się w zlewni. 
W pracy posiłkowano się własnymi pomiarami hydrochemicznymi, które wykonano w 2015 roku. Analizy wykonano w laboratorium hydrochemicznym Katedry Hydrologii Uniwersytetu Gdańskiego, przy użyciu chromatografu jonowego Dionex C1100 i spektrofotometru Nova 400 firmy Merck. Dotyczyły one oznaczenia azotu amonowego, azotu azotanowego(III) i azotu azotanowego(V). Pomiary wartości $\mathrm{pH}$ i temperatury w terenie wykonywano przy użyciu urządzenia wieloparametrowego HQ40 firmy HachLange pomiarów $\mathrm{pH}$ wody i temperatury.

Zgodnie z metodyką obliczeń azotu niejonowego $\mathrm{NH}_{3}$ w wodzie [1] wykonano obliczenia tła korzystając $\mathrm{z}$ równania:

$$
\left(N-\mathrm{NH}_{4}\right)_{t} \cdot(x) \cdot(17,031 / 14,0067)=N H_{3} \mathrm{mg} \cdot \mathrm{dm}^{-3}
$$

gdzie: $\mathrm{N}-\mathrm{NH}_{4}-$ zawartość azotu amonowego,

$\mathrm{x}$ - dane z tablicy metodycznej [2],

$(17,031 / 14,0067)$ - przeliczenie $\mathrm{N}-\mathrm{NH}_{3}$ na $\mathrm{NH}_{3}$.

$\mathrm{W}$ ramach pracy przedstawiono proces transportu zanieczyszczeń rozpuszczonych w wodach rzeki Wąskiej pod kątem niekontrolowanego zrzutu azotu amonowego z zakładu mleczarskiego „Sery” ICC Pasłęk. W modelowaniu przyjęto założenie, że obliczenia zostaną wykonane dla 2 scenariuszy dotyczących przepływu przy odtworzeniu zrzutu wód zanieczyszczonych azotem amonowym z zakładowej oczyszczalni ścieków do potoku Brzezinka, a następnie z wodami potoku Brzezinka do rzeki Wąska. Obliczenia zostały wykonane w warunkach ruchu ustalonego dla natężenia przepływu, który wystąpił w dniach 19 i 20 maja 2014r. w rzece Wąska i potoku Brzezinka z uwzględnieniem piętrzenia na stopniach wodnych „Krosno” i „Drużno” oraz stanu wody w Jeziorze Druzno. Przyjęto założenie, że zrzut wód zanieczyszczonych azotem amonowym wystąpił w ciągu 9 godzin w dniu awarii (pojedyncza fala zanieczyszczeń) oraz przy założeniu, że zrzut wystąpił w ciągu 9 godzin w dniu awarii oraz w ciągu 5 godzin podczas płukania zbiorników w dniu następnym (2 fale zanieczyszczeń). Opracowanie wykonano w programie HEC-RAS (US Army Corps of Engineers, Hydrologic Engineering Centre-River Analysis System).

\section{Charakterystyka hydrologiczna rzeki Wąska}

Rzeka Wąska (rys. 1) jest rzeką II-rzędu, o długości 45,2 km. Powierzchnia zlewni wynosi około $277 \mathrm{~km}^{2}$ [3]. W pobliżu miejscowości Węzina uchodzi ona do jeziora Druzno. Ma cechy rzeki wyżynnej i nizinnej. Górny odcinek rzeki ma charakter górski i podgórski, zaś ujściowy nizinny. Średni spadek rzeki wynosi $2,5 \%$, a przy ujściu $0,02 \%$, zaś przepływ przy ujściu $2,3 \mathrm{~m}^{3} \cdot \mathrm{s}^{-1}$. Średni roczny przepływ dla wielolecia 1961-1990 wynosi $1,99 \mathrm{~m}^{3} \cdot \mathrm{s}^{-1}$. Według Drwala [4] średni roczny przepływ wody $\mathrm{z}$ wielolecia $\mathrm{w}$ rzece Wąskiej wynosi natomiast $2,18 \mathrm{~m}^{3} \cdot \mathrm{s}^{-1}$, co daje wartość dopływu do jeziora Druzno na poziomie około $69 \mathrm{mln} \mathrm{m}^{3}$ wody. Jest to jeden z dwóch głównych dopływów do jeziora Druzno, 
obok rzeki Dzierzgoń, dla którego szacuje się zasilanie na poziomie około 32\% całego dopływu ze zlewni do niecki jeziora Druzno [5]. Współczynnik nieregularności średnich rocznych przepływów na rzece Wąskiej wyniósł 1,96 [6]. Świadczy to o dużej stabilności przepływu rocznego dla rzeki i nieznacznych różnicach pomiędzy przepływem roku wilgotnego i suchego. Głębokość średnia cieku waha się od 0,2 do $1,2 \mathrm{~m}$, a maksymalna dochodzi do $2,5 \mathrm{~m}[7,8]$. Do rzeki Wąskiej dopływa 39 cieków. Jest rzeką asymetryczną, gdzie dominują dopływy lewobrzeżne (21 cieków). Rzeka Wąska wypływa z przykrawędziowej części pojezierza Iławskiego, na zachód od wsi Gudniki [9]. W górnym odcinku przepływa przez kilka zbiorników zaporowych (jeziora Okonie i Zimnochy). Przepływa również przez kilka stawów rybnych. Środkowy odcinek Wąskiej, leżący w obrębie Równiny Warmińskiej, charakteryzuje się głęboką (30 m) doliną, wypełnioną madami i piaskami rzecznymi [9]. Poniżej Pasłęka Wąska wpływa na teren delty Wisły i jest obwałowana ze względu na zagrożenie powodziowe [10]. Na terenie zlewni Wąskiej zlokalizowanych jest 2 jazy, 4 zastawki, 4 pompownie, próg oraz 2 zapory wodne (rys. 1).

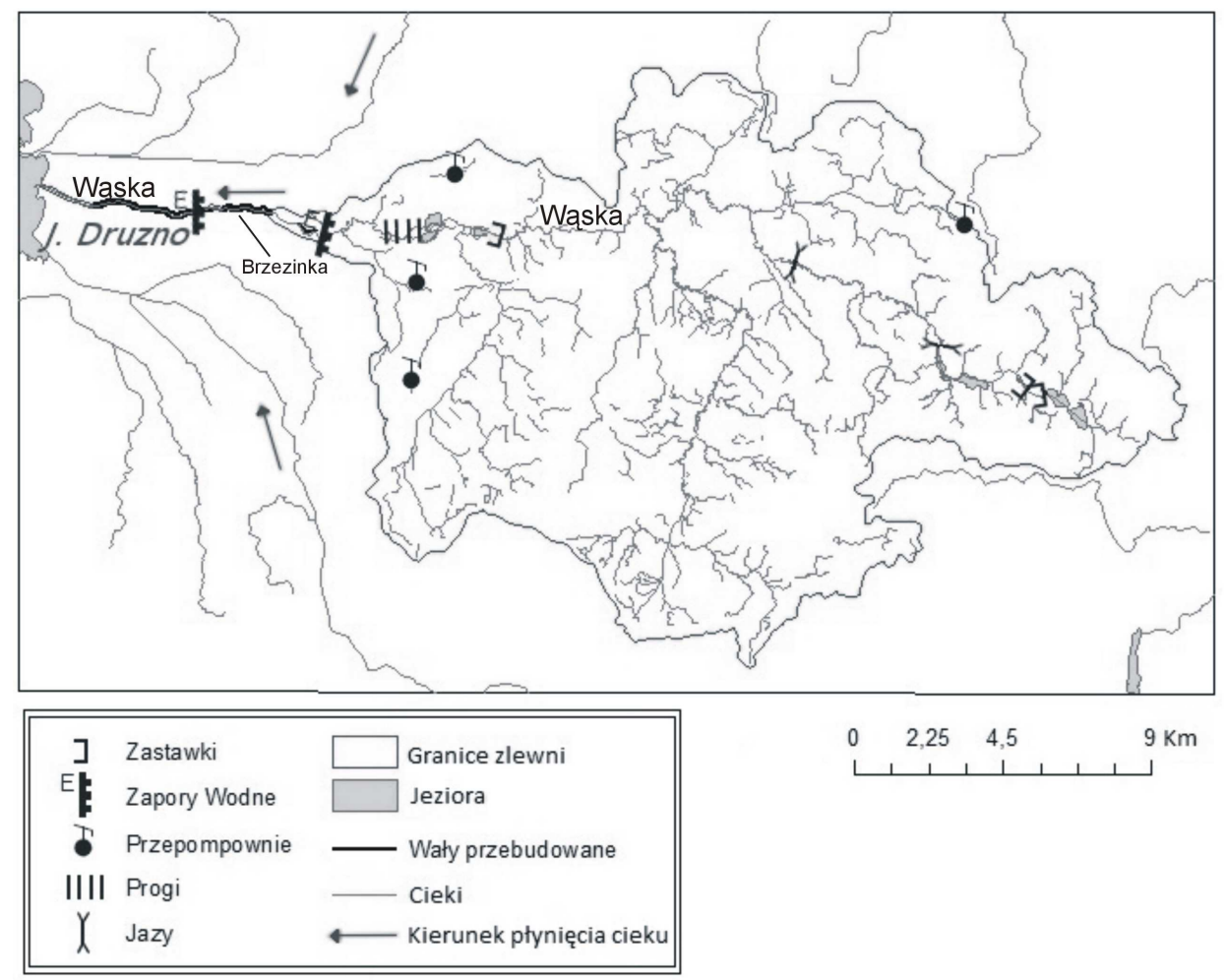

Rys. 1. Szkic hydrograficzny zlewni rzeki Wąska

Fig. 1. Hydrographic draft of the River Wąska catchment 
Jednym z dopływów Wąskiej jest potok Brzezinka, który jest odbiornikiem ścieków pochodzących z zakładu mleczarskiego „Sery” ICC Pasłęk. Ponadto rzeka Wąska jest odbiornikiem ścieków z mechaniczno-biologicznych oczyszczalni ścieków w Pasłęku i Węzinie. Również mleczarnia „Sery” ICC Pasłęk poprzez rzekę Brzezinkę odprowadza około $880 \mathrm{~m}^{3} \cdot \mathrm{d}^{-1}$ ścieków oczyszczanych mechaniczno-biologicznie. Wąska na kilku odcinkach jest źródłem zasilania stawów rybnych, które mają wpływ na jakość wód rzeki. Może być zatem zagrożona zanieczyszczeniem przez wiele źródeł, a w konsekwencji wpływać na zanieczyszczenie samego Jeziora Druzno, do którego uchodzi. Jednakże według Fac-Benedy [11] jezioro cechuje się niejednorodnym środowiskiem wodnym o niestabilnych w czasie parametrach jakościowych. Niejednorodność struktury systemu limnicznego ma swoje odzwierciedlenie m.in. w składzie chemicznym.

\section{Uzyskane wyniki i dyskusja}

\subsection{Stan jakościowy wód analizowanych obiektów na podstawie danych WIOŚ i danych literaturowych}

Stan jakościowy rzeki Wąskiej oceniany był przez WIOŚ w Olsztynie oddział w Elblągu w kilku terminach m.in. w roku 2004, 2007 i 2012. Badania wykonane w 2004 roku dały podstawę do zakwalifikowania rzeki na całej długości do IV klasy czystości [12]. O takiej klasyfikacji zadecydowały: barwa, zawiesina ogólna, substancje organiczne (ChZT-Mn, ChZT-Cr), azot Kjeldahla oraz fosforany. Z kolei badania wykonane w 2007 roku wykazały, że wody rzeki Wąskiej w punkcie pomiarowo-kontrolnym zlokalizowanym na odcinku ujściowym do jeziora Druzno oceniono jako IV klasy [13]. Powodem takiej oceny była wysoka wartość barwy oraz stężenie fosforanów i azotu Kjeldahla. Kolejne badania wykonane w 2012 roku w Jednolitej Części Wód „Wąska od Sały do wpływu do jeziora Druzno" w punkcie Wąska - Węzina potwierdziły, że jej stan jest zły [14]. Przechodząc do szczegółowych badań w 2012 roku ustalono, że azot amonowy w wodach Wąskiej przyjmował wartości w zakresie $0,07-0,88 \mathrm{mg} \cdot \mathrm{dm}^{-3}$, zaś średnia dla całego roku wyniosła $0,29 \mathrm{mg} \cdot \mathrm{dm}^{-3}$. Azot azotanowy(III) w tym czasie mieścił się w przedziale od 0,07 do $0,017 \mathrm{mg} \cdot \mathrm{dm}^{-3}$, przy średniej dla całego roku $0,05 \mathrm{mg} \cdot \mathrm{dm}^{-3}$. Natomiast azot azotanowy $(\mathrm{V})$ mieścił się $\mathrm{w}$ zakresie od 0,26 do $0,93 \mathrm{mg} \cdot \mathrm{dm}^{-3}$, przy średniej w roku wynoszącej $0,74 \mathrm{mg} \cdot \mathrm{dm}^{-3}$. Na podstawie tych wyników można stwierdzić, że występuje sezonowa zmienność stężeń analizowanych wskaźników , o której pisali Drwal i Cieśliński [15]. Według Bogdanowicza [16], najmniejsze stężenia azotu są obserwowane dla sezonu wegetacyjnego (głównie lipiec i sierpień), co związane jest z największą intensywnością procesów wzrostu roślin. Taki rytm wskazuje na dominującą rolę powierzchniowych źródeł zanieczyszczeń [17]. Z kolei według Przybylskiego i in. [18] duży wpływ na stan jakości wód Jeziora Druzno i rzeki Wąskiej wywiera roślinność i ptactwo wodne. W okresie od marca do czerwca na skutek rozpoczęcia wegetacji roślin następował spadek 
zawartości azotu azotanowego(V) w wodzie, natomiast $\mathrm{w}$ październiku następował jego wzrost będący wynikiem obumierania roślinności. Z kolei od czerwca do sierpnia duża ilość ptactwa wodnego przyczyniła się do wzrostu zawartości amoniaku w wodzie Jeziora Druzno (do $3 \mathrm{mg} \cdot \mathrm{dm}^{-3} \mathrm{NH}_{4}$ w sierpniu $1998 \mathrm{r}$.).

Potwierdzeniem powyższych spostrzeżeń są wyniki azotu amonowego w wodach rzeki Wąska w profilu pomiarowym w Węzinie, dla okresu od marca 1997 roku do października 1999 roku wykonane w Katedrze Hydrologii Uniwersytetu Gdańskiego. Zauważyć można w nich duże zróżnicowanie jego stężeń. Wartości te wahały się bowiem od wartości śladowych na poziomie bliskim 0 , które zaobserwowano w maju, lipcu i sierpniu 1997 roku oraz lutym, maju i czerwcu 1998 roku do wartości 1,61 mg. $\mathrm{dm}^{-3}$ zanotowanej w sierpniu 1999 roku (rys. 2).

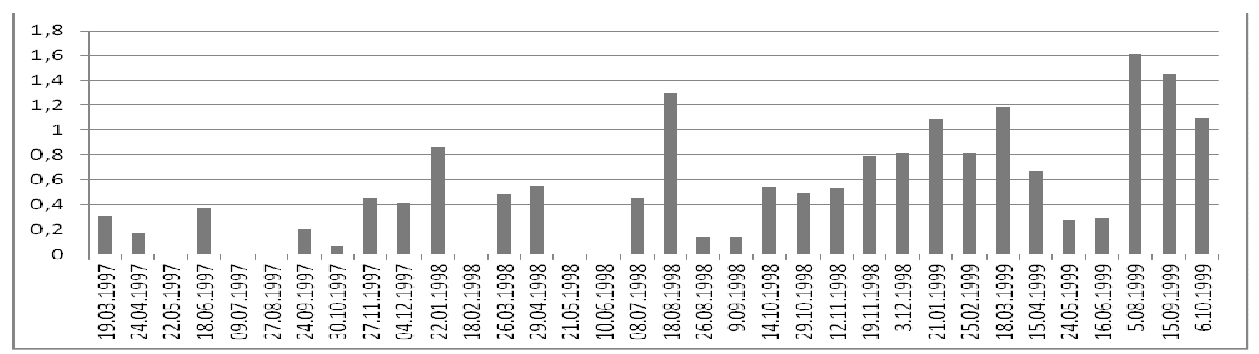

Rys. 2. Stężenie azotu amonowego $\left(\mathrm{mg} \cdot \mathrm{dm}^{-3}\right)$ w wodach rzeki Wąska (profil Węzina) w okresie marzec 1997 - październik 1999

Fig. 2. The concentration of ammonia nitrogen $\left(\mathrm{mg} \cdot \mathrm{dm}^{-3}\right)$ in the waters of the river Wąska (profile Węzina) in the period March 1997 - October 1999

\subsection{Stan jakościowy rzeki Wąskiej w trakcie awarii z 19-20.05. 2014 oraz po awarii w zakładach ,Sery” ICC Pasłęk na podstawie danych WIOŚ}

W trakcie wystąpienia w dniach 19-20.05. 2014 roku awarii w zakładzie „Sery" ICC Pasłęk, w trakcie której wypłynęła do rzeki Wąskiej zanieczyszczona woda lodowa, odpowiednie służby ochrony środowiska przeprowadziły liczne badania jakościowe. Główną przyczyną interwencji WIOS w Olsztynie oddział Elbląg były śnięcia ryb na rzekach Struga Brzezińska i Wąska. W związku z tym dokonano poboru próbek wody do dalszych analiz laboratoryjnych w dniach 20 ., 26. i 27 maja 2014 roku.

W dniu 20.05.2014 roku tj. w drugim dniu awarii odnotowano w punkcie pomiarowym poniżej elektrowni Lisów, że stężenie azotu amonowego wyniosło $1,47 \mathrm{mg} \cdot \mathrm{dm}^{-3}$. W tym samym czasie stężenie azotu azotanowego(III) nie przekraczało wartości 0,05 , zaś azotu azotanowego(V) $0,603 \mathrm{mg} \cdot \mathrm{dm}^{-3}$. Przy kolejnym pomiarze wykonanym w dniu 26.05.2014 roku w tym samym punkcie pomiarowym co poprzednio, stężenie azotu amonowego wynosiło $0,85 \mathrm{mg} \cdot \mathrm{dm}^{-3}$. Pozostałe analizowane wskaźniki tj. azot azotanowy(III) i azot azotanowy(V) osiągnęły odpowiednio wartości $<0,05$ i $0,54 \mathrm{mg} \cdot \mathrm{dm}^{-3}$. W dniu 26.05 .2014 roku wykonano także pomiar w punkcie pomiarowym w miejscowości Węzina. Dla tego punktu 
stężenie azotu amonowego osiągnęło wartość $1,09 \mathrm{mg} \cdot \mathrm{dm}^{-3}$, zaś azotu azotanowego (III) $0,746 \mathrm{mg} \cdot \mathrm{dm}^{-3}$ i azotu azotanowego (V) $0,758 \mathrm{mg} \cdot \mathrm{dm}^{-3}$. W dniu 27.05.2014 roku w punkcie pomiarowym poniżej elektrowni Lisów wielkość azotu amonowego wyniosła $1,05 \mathrm{mg} \cdot \mathrm{dm}^{-3}$, gdy azotu azotanowy (III) $<0,05 \mathrm{mg} \cdot \mathrm{dm}^{-3}$ i azotu azotanowego $(\mathrm{V})-0,509 \mathrm{mg} \cdot \mathrm{dm}^{-3}$. W trakcie kolejnego pomiaru wykonanego w dniu 29.05.2014 roku na posterunku poniżej elektrowni Lisów, stężenie azotu amonowego wyniosło $1,42 \mathrm{mg} \cdot \mathrm{dm}^{-3}$. Dwa pozostałe wskaźniki chemiczne tj. azot azotanowy (III) i azot azotanowy (V) przyjmowały odpowiednio wartości $<0,05$ i $0,767 \mathrm{mg} \cdot \mathrm{dm}^{-3}$. Ostatni pomiar wykonany w dniu 13.06.2014 roku w tym samym punkcie co poprzednio, charakteryzował się stężeniem azotu amonowego na poziomie $0,54 \mathrm{mg} \cdot \mathrm{dm}^{-3}$. W przypadku azotu azotanowego (III) jego wielkość wyniosła w tym dniu $<0,05 \mathrm{mg} \cdot \mathrm{dm}^{-3}$, zaś azotu azotanowego $(\mathrm{V})-0,602 \mathrm{mg} \cdot \mathrm{dm}^{-3}$. Na rysunku 3 przedstawiono zmienność stężeń azotu amonowego w okresie od 20 maja do 13 czerwca 2014 roku w punkcie pomiarowym poniżej elektrowni Lisów, a na rysunku 4 krzywe dobowe przepływów.

Poza wykonaniem pomiarów przez WIOŚ na rzece Wąskiej, były one prowadzone także na Jeziorze Druzno na dwóch punktach pomiarowych. Ze względu na cel pracy uznano, ze istotne są wyniki pomiarów z punktu zlokalizowanego w bliskim sąsiedztwie ujścia rzeki Wąskiej do jeziora. W dniu 27.05.2014 roku zanotowane stężenie azotu amonowego w wodach jeziora nie przekraczało $0,05 \mathrm{mg} \cdot \mathrm{dm}^{-3}$. Z kolei stężenie azotu azotanowego (III) i azotu azotanowego (V) wyniosło dla obu wskaźników $<0,05 \mathrm{mg} \cdot \mathrm{dm}^{-3}$. W terminie 14.07 .2014 roku stężenie azotu amonowego wyniosło $0,2 \mathrm{mg} \cdot \mathrm{dm}^{-3}$, zaś azotu azotanowego (III) $0,045 \mathrm{mg} \cdot \mathrm{dm}^{-3}$ i azotu azotanowego $(\mathrm{V})-0,38 \mathrm{mg} \cdot \mathrm{dm}^{-3}$.

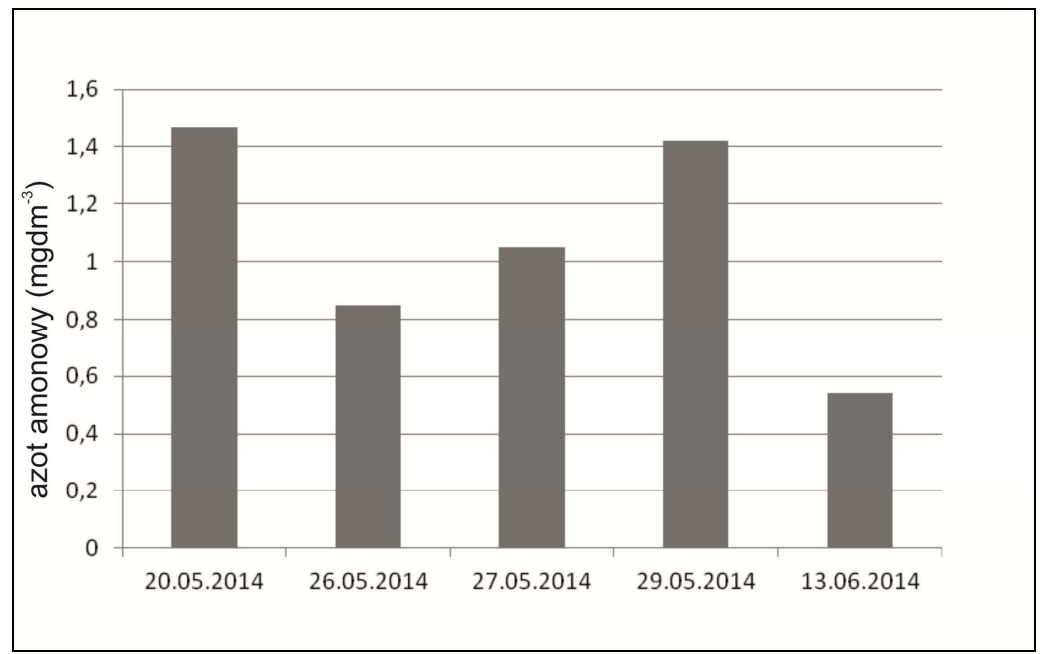

Rys. 3 Stężenie azotu amonowego $\left(\mathrm{mg} \cdot \mathrm{dm}^{-3}\right)$ w wodach rzeki Wąska w wybranych terminach po awarii w zakładzie „Sery” ICC Pasłęk

Fig. 3. The concentration of ammonia nitrogen $\left(\mathrm{mg} \cdot \mathrm{dm}^{-3}\right)$ in the waters of the river Wąska in the selected dates after the accident at the plant "Sery" ICC Pasłęk 


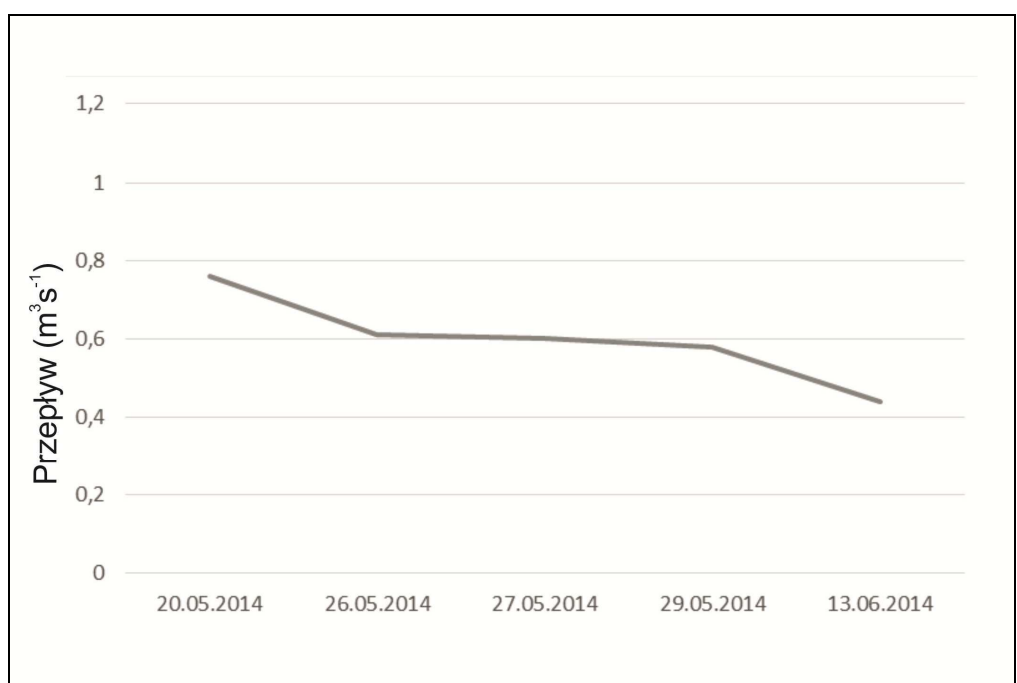

Rys. 4. Krzywa średniego przepływu dobowego na rzece Wąska $\left(\mathrm{m}^{3} \cdot \mathrm{s}^{-1}\right)$ w okresie 20.0513.06.2015 r. w wybranych terminach po awarii w zakładzie „Sery” ICC Pasłęk

Fig. 4. The curve of average daily flow on the river Wąska $\left(\mathrm{m}^{3} \cdot \mathrm{s}^{-1}\right)$ in the period 20.05-13. 06.2015 r. in the selected dates after the accident at the plant "Sery" ICC Pasłęk

Na podstawie uzyskanych wyników wysnuć można kilka wniosków. Po pierwsze w dniu 26.05.2014 roku, a więc około 5 dób od zrzutu azotu amonowego do rzeki Wąskiej jego stężenie było na poziomie pozwalającym na zaliczenie wód rzeki do II klasy czystości. Wskazuje to na dość szybkie przemieszczanie się zanieczyszczeń, pomimo że w tym czasie notowany przepływ był na poziomie niższym od średniego (SSQ). Również samooczyszczanie rzeki charakteryzuje się dużą dynamiką, co powodowało, że w dość krótkim czasie sytuacja wracała do wyjściowej przed awarią. Co istotne w okresie pomiarowym po początkowym obniżeniu stężenia azotu amonowego, w następnych terminach obserwowano fluktuacje uzyskanych wyników (przy jednostajnie zmniejszających się przepływach), co może wskazywać, że o zmienności decydowały warunki naturalne, tak jak to ma miejsce $\mathrm{w}$ przypadku choćby azotu azotanowego(V). Z kolei w punkcie pomiarowym na Jeziorze Druzno w kilka dni po awarii nie zanotowano istotnych zmian $\mathrm{w}$ jakości wody. Wzrosty stężeń azotu amonowego odnotowano następowały w późniejszym okresie, co wskazuje na oddziaływanie warunków naturalnych, choćby takich jak bytowanie ptactwa wodnego, rozwój lub zanikanie biomasy itd.

\subsection{Stan jakościowy wód analizowanych obiektów na podstawie badań własnych}

Na podstawie badań wykonanych w dniu 20.02.2015 roku ustalono, że stężenie azotu amonowego w punkcie pomiarowym na Potoku Brzezinka przed 
wlotem do rzeki Wąskiej $(\mathrm{km} 0+300)$ wynosiło $0,8 \mathrm{mg} \cdot \mathrm{dm}^{-3}$, natomiast w punkcie w Węzinie na rzece Wąskiej tylko $0,2 \mathrm{mg} \cdot \mathrm{dm}^{-3}$. Wartości te wskazują na duże tempo rozcieńczania i samooczyszczania rzeki Wąskiej. Co ważne wartości te są o wiele mniejsze od średniej dla lat 2012-2013 podawanej przez WIOŚ w Elblągu, która wynosi $1,5 \mathrm{mg} \cdot \mathrm{dm}^{-3}$. Również wartości azotu amonowego notowane w punkcie pomiarowym w Węzinie były o wiele wyższe w roku 2004 i 2007 niż ten zanotowany w lutym 2015 roku, gdzie wyniosły odpowiednio 0,69 (2004 rok) i $1,45 \mathrm{mg} \cdot \mathrm{dm}^{-3}$ (2007 rok) oraz $0,2 \mathrm{mg} \cdot \mathrm{dm}^{-3}$ (2015 rok).

\subsection{Obliczenia stężeń azotu amonowego $w$ ściekach $w$ czasie zjawisk ekstremalnych}

Niezwykle istotne znaczenie dla stanu jakościowego Wąskiej mają zjawiska ekstremalne, tym bardziej, że awaria która wystąpiła w 2014 roku była taką sytuacją. Dopuszczalne stężenie jakie może występować w ściekach odprowadzanych z zakładu „Sery” ICC Pasłęk wynosi $10,0 \mathrm{mg} \cdot \mathrm{dm}^{-3}$. Przybylski i in. [18] opierając się na danych dla przepływów średnich (SSQ) z wielolecia podanych przez Drwala [4] oraz niskich (SNQ) podanych przez Pieniążek i in. [19] wyznaczyli zróżnicowanie stężeń azotu amonowego w ściekach przy maksymalnych wartościach stężeń ścieków z Zakładu w ogólnej ilości ścieków rzeki Wąskiej dla różnych przepływów. W efekcie ustalili, że przy przepływach SNQ i maksymalnych stężeniach w ściekach $\left(10 \mathrm{mg} \cdot \mathrm{dm}^{-3}\right)$ wielkość azotu amonowego na Potoku Brzezinka wynosi 7,18 $\mathrm{mg} \cdot \mathrm{dm}^{-3}$, zaś na rzece Wąskiej przy ujściu do Jeziora Druzno - 0,35 $\mathrm{mg} \cdot \mathrm{dm}^{-3}$. Wzrośnie wtedy procentowy udział zanieczyszczeń Zakładu w ściekach rzeki Wąskiej, który wyniesie 44,69\%. Z kolei przy przepływach SSQ wartość azotu amonowego na Potoku Brzezinka nie zmieni się i wyniesie $7,18 \mathrm{mg} \cdot \mathrm{dm}^{-3}$. Natomiast na rzece Wąskiej wartość ta gwałtownie obniży się do $0,05 \mathrm{mg} \cdot \mathrm{dm}^{-3}$ azotu amonowego. Procentowy udział zanieczyszczeń Zakładu w ściekach rzeki Wąskiej zmniejszy się do wartości 6,40\%.

\subsection{Stężenia azotu amonowego $w$ Brzezince $w$ czasie wystąpienia awarii w dniu 19.05.2014r. na podstawie obliczeń}

Stężenie ścieków w Brzezince, w czasie awarii było wynikiem wymieszania się wód Brzezinki, oczyszczonych ścieków zakładowych, oraz zrzutu wód lodowych. Wykorzystując wzór zlewniowej analogii hydrologicznej wyznaczone zostały przepływy rzeki Wąskiej oraz określone odpowiadające im natężenia przepływu w potoku Brzezinka, które wyniosły w dniu awarii $27 \mathrm{dm}^{3} \cdot \mathrm{s}^{-1}$ (jest to ilość wód określana dla końcowego odcinka rzeki Brzezinka). W rzeczywistości w czasie awarii powyżej miejsca zrzutu oczyszczonych ścieków zakładowych przepływ wód Brzezinki, był bliski zeru. Należy zaznaczyć, że główne zasilanie w wody tego odcinka ma miejsce poprzez gwałtowne spływy z trasy S7 co nie miało miejsca, gdyż w dniu awarii nie było opadów. Badania z lutego 2015 roku potwierdzają powyższe informacje, gdyż przy braku opadów, przepływ w Brzezince powyżej miejsca zrzutu ścieków wyniósł ok. $0,3 \mathrm{dm}^{3} \cdot \mathrm{s}^{-1}$ [18], co jest war- 
tością znikomą w kontekście przepływów z oczyszczalni, a tym bardziej w czasie zrzutu wód lodowych.

Wartość $27 \mathrm{dm}^{3} \cdot \mathrm{s}^{-1}$ można uwzględnić przy wyznaczeniu przepływów dopiero na końcowym odcinku rzeki Brzezinki. Do obliczeń stężenia zanieczyszczeń przyjęto takie rozwiązanie. Wobec braku informacji o stężeniach zanieczyszczeń z wielolecia oraz analizując zlewnię rzeki przyjęto, że jej stan fizycznochemiczny będzie odpowiadał ilości substancji w rzece Wąskiej [18]. Tło zanieczyszczeń rzeki Brzezinki wynosić będzie, dla wartości maksymalnej amoniaku niejonowego $0,0823 \mathrm{mg} \mathrm{NH} \cdot \mathrm{dm}^{-3}$ (azot amonowy $1,45 \mathrm{mg} \mathrm{NH}_{3} \cdot \mathrm{dm}^{-3}$ ).

Stężenia zanieczyszczeń z oczyszczalni ścieków w chwili awarii nie są dokładnie znane aczkolwiek na pewno odbiegały od średnich parametrów stężeń zanieczyszczeń z wielolecia. Wiadomo jednak, iż w dniu 13 maja 2014r. doszło do zrzucenia 4600 litrów śmietany. Spowodowało to zapewne znaczny spadek efektywności oczyszczania ścieków, co skutkowało podwyższonymi parametrami na wylocie z oczyszczalni do rzeki Brzezinki. Ocenia się, że odbudowa osadu czynnego mogła trwać przez kilkadziesiąt dni i zapewne pogorszone parametry oczyszczania były również w momencie zrzutu wody lodowej jak i długi czas po tym zdarzeniu. Zatem należy uznać, ze pomiary z dnia 27 maja 2014r. są najbardziej zbliżone do stanu fizyczno-chemicznego ścieków podczas awarii w zakładzie [20]. Wyznaczono wtedy stężenia zanieczyszczeń, a przepływ ścieków wynosił $19 \mathrm{dm}^{3} \cdot \mathrm{s}^{-1}$. Wobec powyższego, poziom zanieczyszczenia amoniakiem niejonowym wyniesie $0,959 \mathrm{mg} \mathrm{NH} \mathrm{NH}_{3} \cdot \mathrm{dm}^{-3}$.

Do wody lodowej, w najgorszym wariancie, przedostało się $300 \mathrm{~kg}$ amoniaku [21]. Temperatura wody wynosiła $1-3^{\circ} \mathrm{C}$, a $\mathrm{pH}$ dla wody lodowej wynosi 7. Roztwór zawierał $540 \mathrm{~m}^{3}$ wody zanieczyszczonej amoniakiem. W związku z tym, że amoniak bardzo łatwo rozpuszcza się w wodzie [22], zakłada się, że uległ rozpuszczeniu w całości. Wobec tego stężenie amoniaku w rzece Brzezince, $\mathrm{w}$ przeliczeniu na azot amonowy wynosiło $128,78 \mathrm{mg} \cdot \mathrm{dm}^{-3}$. Z kolei stężenie niejonowej formy azotu w rzece Brzezince, w czasie awarii wynosiło maksymalnie $34,61 \mathrm{mg} \cdot \mathrm{dm}^{-3}$ przy przepływie $72,66 \mathrm{dm}^{3} \cdot \mathrm{s}^{-1}$ oraz przy $\mathrm{pH}=9,24$ i temp. $=8,33^{\circ} \mathrm{C}$.

\subsection{Hydrauliczne obliczenia migracji amoniaku}

W obliczeniach odtworzono sieci cieków wraz z ich węzłami połączeniowymi oraz ich geodezyjne położenie $w$ terenie $[23,24]$. Wykorzystane zostały dane dotyczące geometrii przekrojów poprzecznych pozyskane z dokumentacji projektowej, mapy topograficznej oraz sytuacyjno-wysokościowej. Uwzględniono 143 przekroje w odstępach $100 \mathrm{~m}$. Zestawione zostały także dane dotyczące współczynnika oporów, który określono zgodnie z formułą Manninga [25]. Dodatkowo wyznaczone zostały przekroje pośrednie (co $20 \mathrm{~m}$ ) na drodze interpolacji geometrycznej, którą umożliwia program HEC-RAS, a którą opisał m.in. Leonard [26, 27]. Uzyskany profil podłużny rzeki Wąskiej przedstawiono na rysunku 5. 
Następnie wykonane zostały obliczenia hydrauliczne dla rozkładu przepływów obliczonych w dniu 19 i 20 maja 2014r. oraz dwóch wariantów zrzutu ścieków przyjmując średnie dobowe natężenia przepływu wody w rzece Wąskiej, potoku Brzezinka oraz w miejscu dopływu ścieków do odbiornika. Wyniki położenia zwierciadła wody dla przyjętego rozkładu przepływów przedstawiono na profilu rzeki Wąskiej (rys. 6), a wyniki rozkładu prędkości (w zestawieniu z przepływami charakterystycznymi SNQ i SSQ) na rysunku 7.

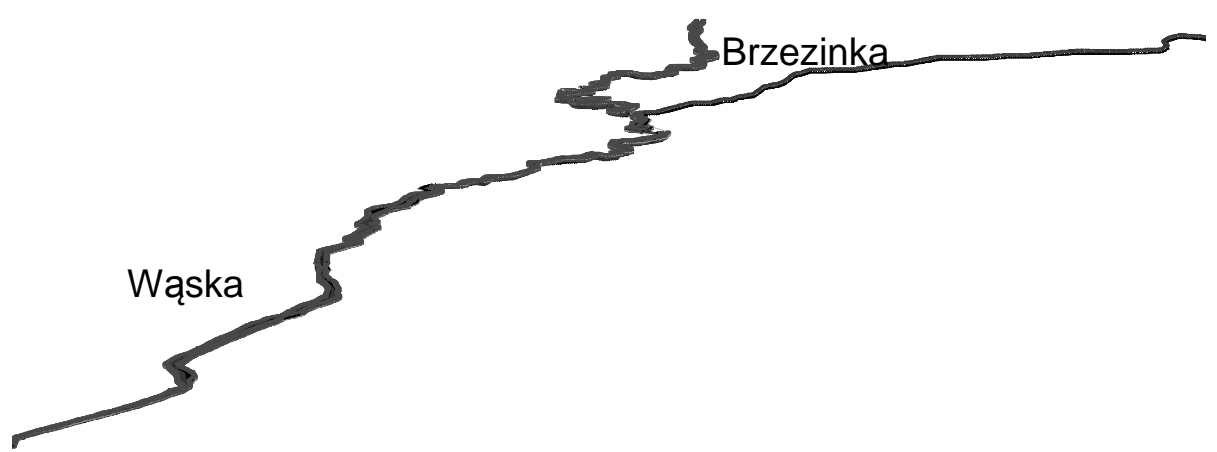

\section{ujście do Jeziora Drużno}

Rys. 5. Model numeryczny odcinka rzeki Wąskiej oraz odcinka potoku Brzezinka utworzony w programie HEC-RAS

Fig. 5. The numerical model of stretch of the river Wąska and stretch Brzezinka Stream created in HEC-RAS

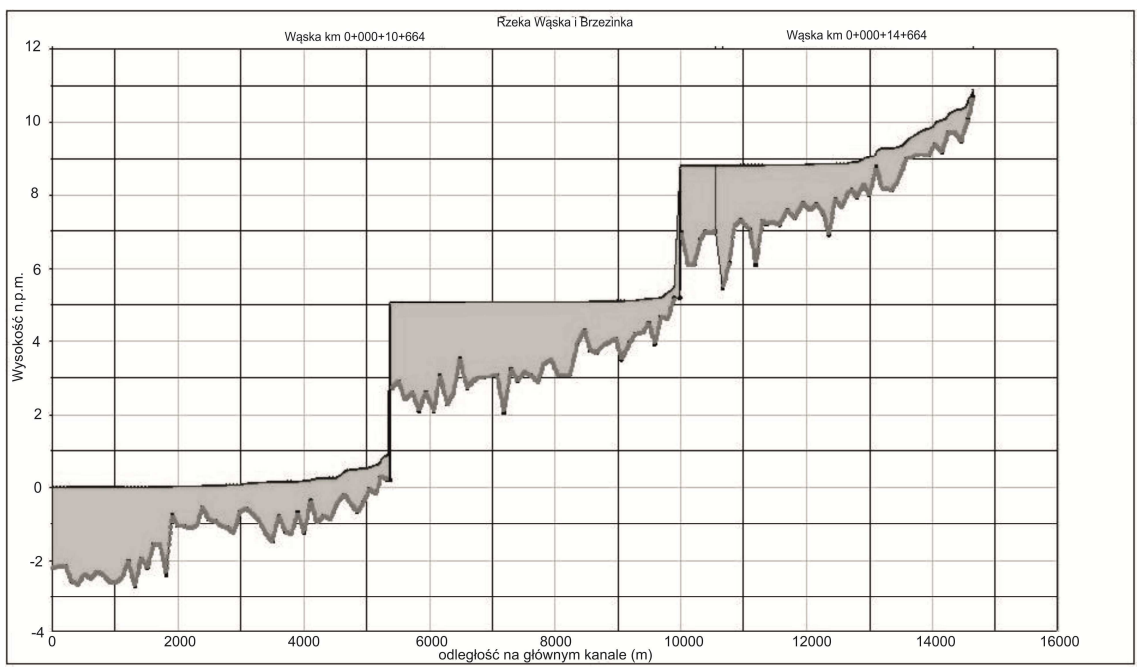

Rys. 6. Położenie zwierciadła wody dla przyjętych przepływów w profilu rzeki Wąska wyniki obliczeń hydraulicznych

Fig. 6. The position of the water table for the accepted flow profile river Wąska - the results of hydraulic calculations 


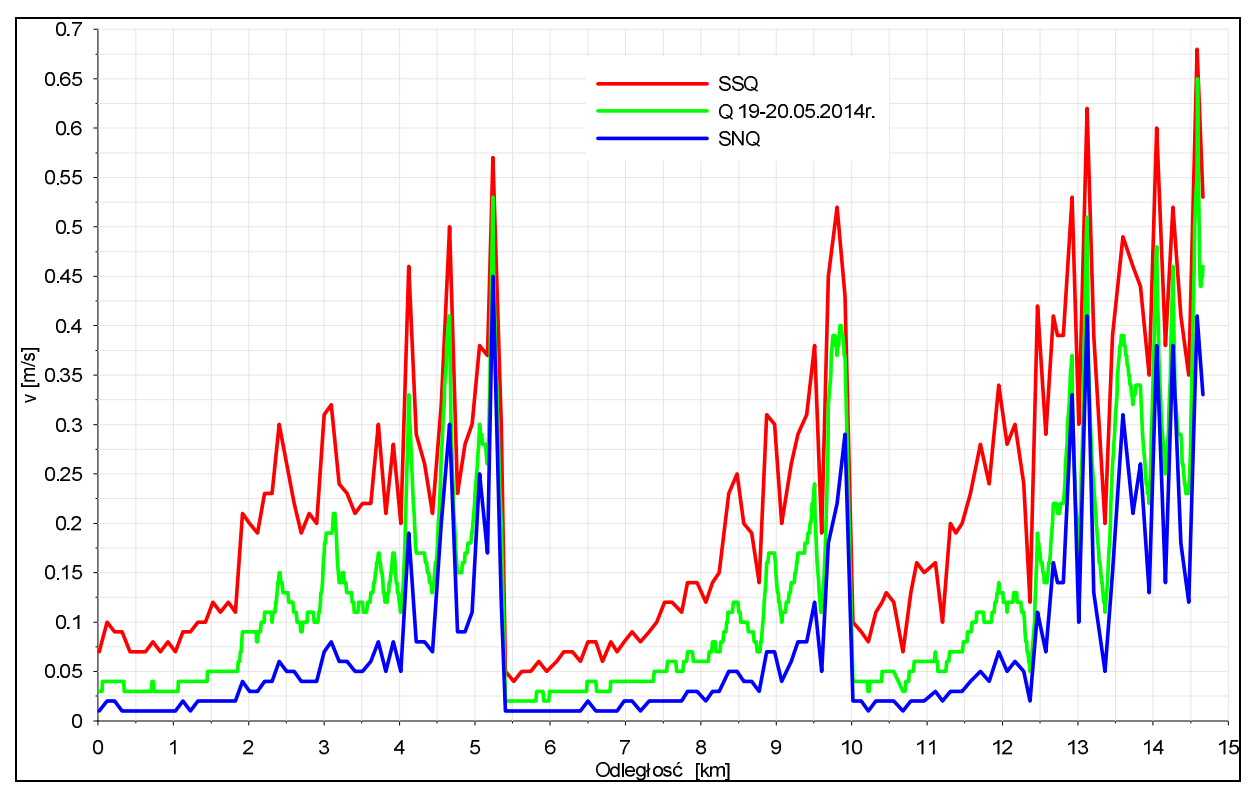

Rys. 7. Rozkład prędkości średniej dla przyjętego rozkładu przepływów w dniu 19 i 20 maja na tle przepływu miarodajnego SSQ oraz SNQ w profilu rzeki Wąska - wyniki obliczeń hydraulicznych

Fig. 7. Distribution of average speed for the assumed distribution of flows on 19 and 20 May against the flow of authoritative SSQ and SNQ in profile river Wąska - the results of hydraulic calculations

\subsection{Wyniki stężeń amoniaku na podstawie obliczeń modelowych}

Przeprowadzono analizę migracji amoniaku jako substancji rozpuszczonej, biernej i nierozkładalnej w warunkach nieustalonych dla ustalonych warunków przepływu w dniu 19 i 20 maja 2014 r., rozwiązując numerycznie jednowymiarowe równanie nieustalonego transportu substancji rozpuszczonej. Do rozwiązania zastosowano moduł jakości wody w programie HEC-RAS. Moduł ten wykorzystuje wyniki obliczeń hydraulicznych uzyskane za pomocą modułu hydraulicznego, nawiązując do zdefiniowanych tam przekrojów obliczeniowych [28]. Wyniki te wykorzystane zostały jako dane wejściowe do badania rozkładu zanieczyszczeń w wodach Wąskiej i Brzezinki.

W module jakości wody programu HEC-RAS przyjęto odpowiednie warunki graniczne. Jako warunek początkowy przyjęto zerowo stężenie amoniaku w każdym z cieków. Zrzut ścieków z oczyszczalni został odtworzony przez włączenie dopływu bocznego w ilości wód zrzucanych z Zakładu do wód Brzezinki. Przyjęto dwa scenariusze zrzutu utworzone na podstawie opisu przebiegu awarii $[23,24]$. Zgodnie $\mathrm{z}$ nim, rozszczelnienie instalacji z amoniakiem oraz jego wyciek do wody lodowej mógł wystąpić pomiędzy godziną $0^{00}$ a $4^{00}$ w nocy z 18/19 maja 2014 r. Jak wynika z opracowania [21], możliwe były trzy scenariusze 
awarii, a uwolniona masa amoniaku mogła wynieść w sumie od 8,4 do $300 \mathrm{~kg}$. Wyciek powstał w jednym ze zbiorników wody lodowej o pojemności $180 \mathrm{~m}^{3}$. W dniu 19 maja zrzucono wodę ze zbiorników wody lodowej poprzez system kanalizacji deszczowej do potoku Brzezinka. Zrzut rozpoczęto ok. godz. 14을 a zakończono ok. godz. $21^{00}$. W tym czasie opróżniono 3 zbiorniki wody lodowej, po $180 \mathrm{~m}^{3}$ każdy (w sumie zrzucono $540 \mathrm{~m}^{3}$ wody). Następnie w dniu 20 maja 2014 r. rozpoczęto dopłukiwanie instalacji, a woda była odprowadzana od ok. godz. $9^{\underline{00}}$ do ok. godz. 14으. W tym czasie przepłukano 2 zbiorniki zrzucając dodatkowo $360 \mathrm{~m}^{3}$ wody, $\mathrm{z}$ niewielkimi ilościami amoniaku (po płukaniu zbiorników).

Do symulacji przyjęto następujące dwa, najmniej korzystne scenariusze. W pierwszym założono, że amoniak do wód Brzezinki dostał się wraz z wodami zrzucanymi w dniu 19 maja. Przyjęto największe jego stężenie wynikające z maksymalnej ilości (300 kg), jaka mogła dostać się do wody lodowej [21]. W sumie daje to stężenie ok. $439,81 \mathrm{mg} \mathrm{NH} \cdot \mathrm{dm}^{-3}$ - i takie stężenie przyjęto w zrzucanej wodzie w ciągu 9 godzin, od $14^{00}$ do $23^{00}$. Zrzut wód z dopłukiwania potraktowano jako zrzut wód o znikomo małym stężeniu, (scenariusz nr 1). Po wymieszaniu $\mathrm{z}$ wodami Brzezinki, dla zadanego rozkładu przepływów w dniu 19 i 20 maja 2014 r. stężenie amoniaku wyniosło $128,78 \mathrm{mg} \mathrm{NH}_{3} \cdot \mathrm{dm}^{-3}$.

W drugim scenariuszu przyjęto identyczne założenia jak w pierwszym co do zrzutu w dniu 19 maja oraz założono mało prawdopodobną sytuację, ale najmniej korzystną z punktu widzenia zagrożenia środowiska, że w czasie zrzutu wód $\mathrm{z}$ dopłukiwania zbiorników w dniu 20 maja stężenie amoniaku w wodzie wynosiło $439,81 \mathrm{mg} \mathrm{NH}_{3} \cdot \mathrm{dm}^{-3}$.

Następnie przeprowadzono obliczenia numeryczne propagacji fali wód zanieczyszczonych amoniakiem dla obliczonego rozkładu przepływów w dniu 19 i 20 maja dla dwóch przyjętych i omówionych powyżej scenariuszy zrzutu. Przeprowadzone obliczenia umożliwiły śledzenie w czasie zmian stężenia amoniaku wzdłuż rzeki Wąskiej, co pozwoliło na określenie czasu przemieszczenia fali zawierającej zanieczyszczenia danego przekroju charakterystycznego. Wyniki te $\mathrm{w}$ postaci graficznej przedstawiono $\mathrm{w}$ postaci zmian stężeń amoniaku w wodach rzeki Wąskiej w charakterystycznym przekroju w miejscu ujścia do Jeziora Druzno dla obu wariantów obliczeniowych (rys. 8, rys. 9).

W przypadku zrzutu wód lodowych zanieczyszczonych amoniakiem wg scenariusza $\mathrm{nr} 1$ (pojedyncza fala zanieczyszczeń) przebieg propagacji fali zanieczyszczeń w wodach rzeki Wąskiej zależy od warunków przepływu panujących wzdłuż poszczególnych cieków, co potwierdzają badania Krukowskiego [29] dla rzeki Wkra. W rzece Wąskiej oraz potoku Brzezinka, stężenie po wprowadzeniu wód zanieczyszczonych do wód Brzezinki wynosi ok. $C=128,78 \mathrm{mg} \mathrm{NH} \cdot \mathrm{dm}^{-3}$. Do stopnia „Krosno” ( $\mathrm{km} \mathrm{9+959)} \mathrm{możliwe} \mathrm{jest} \mathrm{prze-}$ mieszczenie fali zawierającej amoniak, która dotarła około godz. $21^{\underline{00}}$ tego samego dnia i osiągnęła maksymalne stężenie $C=6,92 \mathrm{mg} \cdot \mathrm{dm}^{-3}$, a następnie spadła do wartości bliskiej zeru ok. godz. $14^{30} 20.05 .2014$ r. W przekroju stopnia wod- 
nego „Drużno” (km 5+396) amoniak można odnotować ok. godz. 19³0 20.05.2014 r. i osiąga maksymalne stężenie $C=5,66 \mathrm{mg} \cdot \mathrm{dm}^{-3}$, a spada do wartości bliskiej zeru około godz. $23^{\underline{00}}$ 21.05.2014 r. Możliwe przemieszczenie wód zanieczyszczonych amoniakiem do Jeziora Druzno, które można oszacować ok. $14^{00} 21.05 .2014 \mathrm{r}$. na $C=5,11 \mathrm{mg} \cdot \mathrm{dm}^{-3}$, zaś około północy z 22/23.05.2014 r. spadają do wartości bliskiej zeru.

W przypadku zrzutu wód lodowych zanieczyszczonych amoniakiem wg scenariusza nr 2 (dwie fale zanieczyszczeń) w rzece Wąskiej oraz potoku Brzezinka, stężenie po wprowadzeniu wód zanieczyszczonych do wód Brzezinki wynosi ok. $C=130 \mathrm{mg} \mathrm{NH} \cdot \mathrm{dm}^{-3}$. Czoło pierwszej fali zanieczyszczeń, których zrzut rozpoczęto 19 maja ok. godz. 14, do elektrowni „Krosno” (km 9+959) osiągnęło maksymalne stężenie $C=6,92 \mathrm{mg} \cdot \mathrm{dm}^{-3} \mathrm{ok}$. godz. $21^{00}$ tego samego dnia i osiąga. Druga fala zanieczyszczeń, których zrzut rozpoczęto 20 maja ok. godz. 900 , do elektrowni „Krosno” (km 9+959) osiągnęło maksymalne stężenie ok. $C=6,50 \mathrm{mg} \cdot \mathrm{dm}^{-3}$ ok. godz. $14^{00} 20.05 .2014 \mathrm{r}$. I już praktycznie tu, przed zaporą elektrowni „Krosno”, dochodzi do połączenia z pozostałością amoniaku z pierwszej fali zanieczyszczeń, w zasięgu cofki wywołanej stopniem piętrzącym „Krosno”. Stężenie amoniaku w rejonie elektrowni „Krosno” spada do wartości bliskiej zeru ok. godz. $6^{00} 21.05 .2014 \mathrm{r}$.

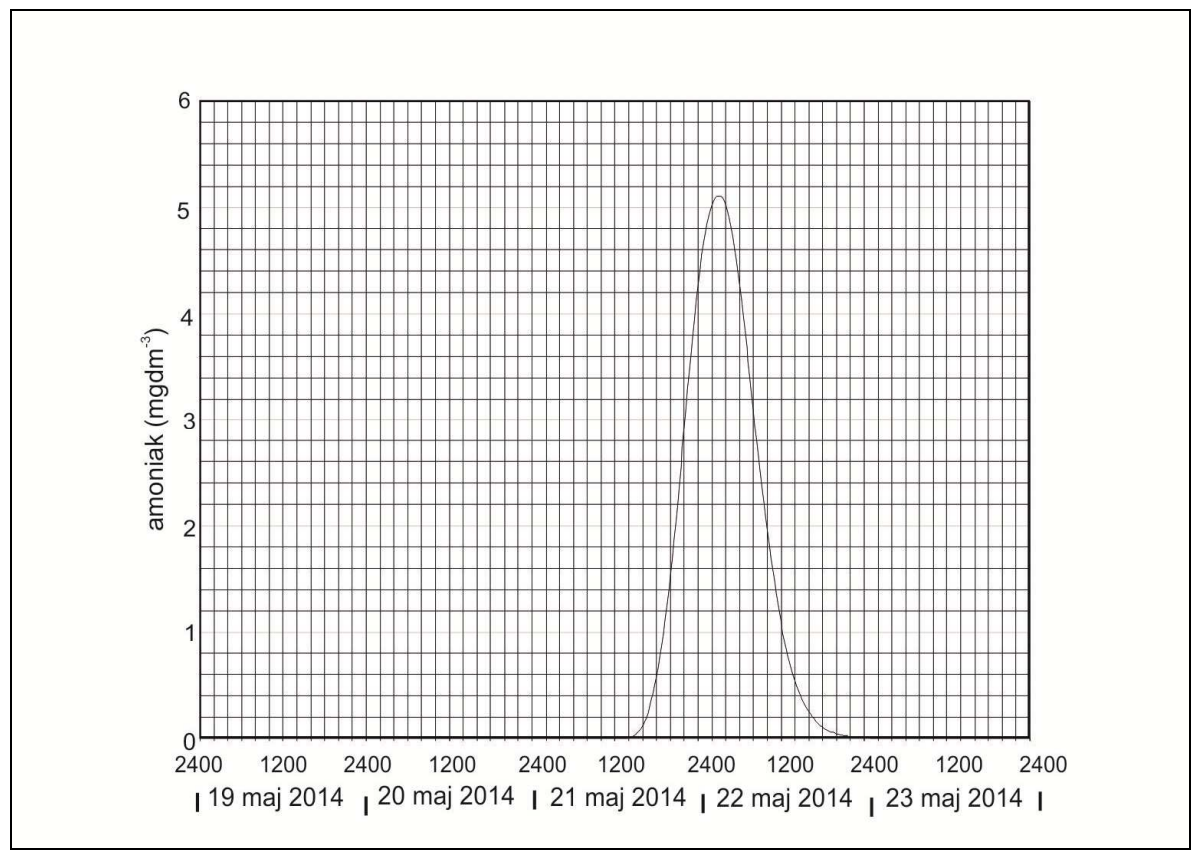

Rys. 8. Zmiana stężenia amoniaku na ujściu Wąskiej do Jeziora Druzno, wariant nr 1

Fig. 8. Changing the concentration of ammonia at the river Wąska mouth to Lake Druzno, option 1 


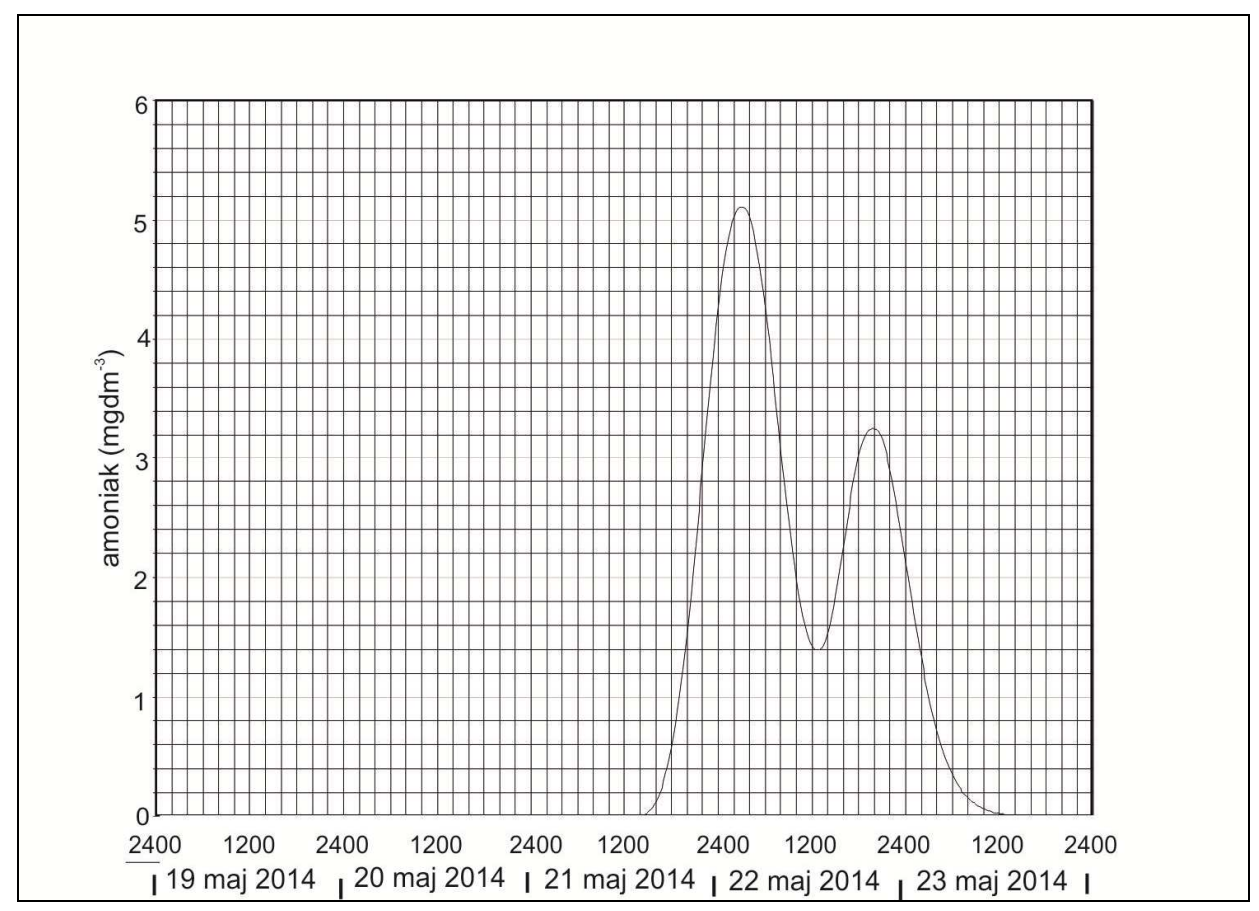

Rys. 9. Zmiana stężenia amoniaku na ujściu Wąskiej do Jeziora Druzno, wariant nr 2

Fig. 9. Changing the concentration of ammonia at the river Wąska mouth to Lake Druzno, option 2

W przekroju stopnia wodnego „Drużno” (km 5+396) dochodzi już do połączenia obu fal, a maksymalne stężenie amoniaku $C=5,66 \mathrm{mg} \cdot \mathrm{dm}^{-3}$ występuje ok. godz. $19^{30} 20.05 .2014$ r. a następnie spada do wartości bliskiej zeru ok. godz. $15 \underline{00} 22.05 .2014$ r. Do Jeziora Druzno wody zanieczyszczone amoniakiem odnotowuje się ok. $14^{00} 21.05 .2014$ r., gdzie amoniak osiąga maksymalne stężenie $C=5,11 \mathrm{mg} \cdot \mathrm{dm}^{-3}$, by ok. godz. $10^{00} 23.05 .2014 \mathrm{r}$. spaść do wartości bliskiej zeru.

Całkowity ładunek amoniaku z rzeki Brzezinki przepływał rzeką Wąską przez maksymalnie 44 godziny. Powyższe oznacza, że w dniu 23.05.2014 r. około godziny $12.00 \mathrm{w}$ południe nie było już w rzece amoniaku pochodzącego z zanieczyszczonej wody lodowej.

W przypadku zrzutu wód lodowych zanieczyszczonych amoniakiem wg scenariusza nr 2 (dwie fale zanieczyszczeń) w rzece Wąskiej oraz potoku Brzezinka, stężenie po wprowadzeniu wód zanieczyszczonych do wód Brzezinki wynosi ok. $C=130 \mathrm{mg} \mathrm{NH} \cdot \mathrm{dm}^{-3}$. Czoło pierwszej fali zanieczyszczeń, których zrzut rozpoczęto 19 maja ok. godz. 14, do elektrowni „Krosno” (km 9+959) osiągnęło maksymalne stężenie $C=6,92 \mathrm{mg} \cdot \mathrm{dm}^{-3} \mathrm{ok}$. godz. $21^{00}$ tego samego dnia i osiąga. Druga fala zanieczyszczeń, których zrzut rozpoczęto 20 maja ok. godz. 900 , do elektrowni „Krosno” (km 9+959) osiągnęło maksymalne stężenie ok. $C=6,50 \mathrm{mg} \cdot \mathrm{dm}^{-3}$ ok. godz. $14^{00} 20.05 .2014 \mathrm{r}$. I już praktycznie tu, przed za- 
porą elektrowni „Krosno”, dochodzi do połączenia z pozostałością amoniaku z pierwszej fali zanieczyszczeń, w zasięgu cofki wywołanej stopniem piętrzącym „Krosno”. Stężenie amoniaku w rejonie elektrowni „Krosno” spada do wartości bliskiej zeru ok. godz. $6^{00}$ 21.05.2014 r. W przekroju stopnia wodnego „Drużno” (km 5+396) dochodzi już do połączenia obu fal, a maksymalne stężenie amoniaku $C=5,66 \mathrm{mg} \cdot \mathrm{dm}^{-3}$ występuje ok. godz. $19^{30} 20.05 .2014 \mathrm{r}$. a następnie spada do wartości bliskiej zeru ok. godz. $15^{\underline{00}} 22.05 .2014$ r. Do Jeziora Druzno wody zanieczyszczone amoniakiem odnotowuje się ok. 14으 21.05 .2014 r., gdzie amoniak osiąga maksymalne stężenie $C=5,11 \mathrm{mg} \cdot \mathrm{dm}^{-3}$, by ok. godz. $10^{00}$ 23.05.2014 r. spaść do wartości bliskiej zeru

Całkowity ładunek amoniaku z rzeki Brzezinki przepływał rzeką Wąską przez maksymalnie 44 godziny. Powyższe oznacza, że w dniu 23.05.2014 r. około godziny $12.00 \mathrm{w}$ południe nie było już $\mathrm{w}$ rzece amoniaku pochodzącego z zanieczyszczonej wody lodowej.

\subsection{Przemiany amoniaku w rzece Wąskiej}

W wodach powierzchniowych świeżo zanieczyszczonych np. ściekami bytowymi, azot występuje głównie w formie organicznej. W wodzie następuje rozkład białka do amoniaku. Jeśli w rzece panują warunki aerobowe, zachodzi proces nitryfikacji a jony amonowe ulegają $\mathrm{w}$ środowisku aerobowym utlenieniu. Sama nitryfikacja to proces utleniania amoniaku i soli amonowych do azotanów prowadzony przez bakterie nitryfikacyjne. Optymalna dla nitryfikacji wartość pH mieści się w zakresie 6,5 - 8,0 [30]. Szybkość procesu nitryfikacji zależy w głównej mierze od temperatury. Reiman badając nitryfikację ścieków stwierdził, że szybkość utleniania azotu amonowego wynosi $0,102 \mathrm{mg} \cdot \mathrm{dm}^{-3}$ $\mathrm{N}-\mathrm{NH}_{4}$ na godzinę w temperaturze $15^{\circ} \mathrm{C}$ oraz $0,26 \mathrm{mg} \cdot \mathrm{dm}^{-3} \mathrm{~N}-\mathrm{NH}_{4}$ na godzinę $\mathrm{w}$ temperaturze $30^{\circ} \mathrm{C}$ [30]. Powyższe zgodne jest również z badaniami Groenewag $\mathrm{i}$ in. [31]. Do obliczeń przyjęto, szybkość utleniania azotu amonowego w odniesieniu do temperatury w wysokości $0,123 \mathrm{mg} \cdot \mathrm{dm}^{-3} \mathrm{~N}_{-} \mathrm{NH}_{4}$.

Procesy nitryfikacji mogą mieć istotny wpływ na zmiany zawartości tlenu w rzece. Sumarycznie w procesie nitryfikacji zużywa się 4,33 mg tlenu na $1 \mathrm{mg}$ azotu (z czego 3,22 mg tlenu na utlenienie azotu amonowego, 1,11 mg tlenu na utlenienie azotanów [30]. Wyniki próbek WIOŚ nie wskazują aby w rzece pomiędzy 20.05.2014 r. a 13.06.2014 r. panowały warunki odbiegające od normy stężenie rozpuszczonego tlenu utrzymywała się pomiędzy $5,2-5,8 \mathrm{mg} \cdot \mathrm{dm}^{-3} \mathrm{O}_{2}$.

W niniejszym badaniu przyjęto, że czas przepływu ścieków wynosił: do Stopnia wodnego Krosno (9+959) 7 godzin, do Stopnia wodnego Drużno (5+396) 24,5 godziny , do Jeziora Druzno (0+013) 50 godzin.

Zanieczyszczenia amoniaku z Brzezinki, niosące ładunek azotu wynikający ze zrzutu wód lodowych oraz z pozostałych źródeł jak oczyszczalnia zakładowa nigdy nie dotarły do Jeziora Druzno. Uległy bowiem przede wszystkim nitryfikacji na odcinku pomiędzy km 5+396 a 0+013. Na odcinku od km 10+637 do 
5+396 poziom zanieczyszczeń azotem amonowym zmieniał w znacznym stopniu odczyn rzeki, a maksymalne stężenia zanieczyszczeń utrzymywały się od 2 do 4 godzin.

\section{Wnioski}

Na podstawie uzyskanych wyników i analiz wyciągnąć można kilka istotnych wniosków.

1. Całkowity ładunek amoniaku z rzeki Brzezinki utrzymywał się w rzece Wąskiej przez maksymalnie 50 godzin.

2. Obliczenia wskazują, że w dniu 23.05.2014r. około godziny $12.00 \mathrm{w}$ południe nie było już w rzece amoniaku pochodzącego z zanieczyszczonej wody lodowej.

3. Wyniki badań laboratoryjnych Wojewódzkiego Inspektoratu Ochrony Środowiska z dnia 20.05.2014r. zebrane w miejscu poniżej elektrowni Druzno (profil Lisów) (WIOŚ 2014) wskazują, zawartość azotu amonowego w rzece była na poziomie nieznacznie wyższym od maksymalnej z wielolecia tj. $1,47 \mathrm{mg} \cdot \mathrm{dm}^{-3}$ (wobec $1,45 \mathrm{mg} \cdot \mathrm{dm}^{-3}$ ). W tym czasie nie było tam jeszcze wód zanieczyszczonych wodami lodowymi.

4. Maksymalne stężenia azotu amonowego występowały w okresie od 2 do 4 godzin.

5. Hydrologicznie rzeka Wąska ma zdolności znacznego samooczyszczania i to spowodowało, że zanieczyszczenie mogło wywołać efekt letalny dla organizmów wodnych części rzeki, ale i lokalny bowiem czoło fali zanieczyszczeń nie osiągnęło ujściowego odcinka rzeki ani Jeziora Druzno

6. Rzeka Wąska dość szybko powróciła do stanu pierwotnego. Świadczą o tym odnotowane stężenia w wodach rzeki tuż przed wpłynięciem do Jeziora Druzno, a także w wodach samego jeziora oraz wyniki badań laboratoryjnych w okresie kilku, kilkunastu dni po awarii.

W efekcie można stwierdzić, że zanieczyszczenia jakie wprowadzone zostały poprzez rzekę Brzezinkę do Wąskiej miały charakter lokalny. Zatem należy wykluczyć stan klęski ekologicznej tego regionu. Spowodowały one „uszczerbek" pewnych form życia biologicznego m.in. ryb, ale tylko w górnym i środkowym odcinku rzeki Wąskiej.

\section{Literatura}

[1] Environmental Assessment and Restoration Bureau of Laboratories: Tallahassee, Florida 2001.

[2] Thurston R.V., Russo R.C., Emerson K.: Aqueous Ammonia Equilibrium Calculations, Technical Report, No. 74-1, Fisheries Bioassay Laboratory, Montana State University 1974.

[3] Drwal J. (red.): Basen Jeziora Druzno. Regionalny system przyrodniczo-techniczny, Wydawnictwo Uniwersytetu Gdańskiego, Gdańsk 1991. 
[4] Drwal J. (red): Wody Delty Wisty, część wschodnia, Gdańskie Towarzystwo Naukowe, Gdańsk 2002.

[5] Cieśliński R.: Rola niecki jeziora Druzno w transformacji odptywu z druznieńskiego systemu hydrograficznego, [w:] J. Drwal (red.), Wody delty Wisły - część wschodnia, GTN, Gdańsk 2002, s. 95-109.

[6] Cieśliński R.: Komentarz do mapy hydrograficznej w skali 1:50000, arkusz N-34-63-D Elblag-Płd., Z.U.G.I.K. PRYZMAT, Częstochowa 2007.

[7] Dębowski P.: Ichtiofauna dorzecza Waskiej, Rocz. Nauk. PZW, nr 9, 1996, s. 37-50.

[8] Radtke G., Bernaś R., Dębowski P., Skóra M.: Ichtiofauna dorzecza rzeki Elblag, Rocz. Nauk. PZW, nr 24, 2011, s. 97-114.

[9] Augustowski B. (red.): Żuławy Wiślane, Wyd. GTN, Gdańsk 1976.

[10] Cebulak K.: Delta Wisty powyżej i poniżej poziomu morza, Wyd. Stowarzyszenie Żuławy i Lokalna Grupa Działania Żuławy i Mierzeja, Nowy Dwór Gdański 2010.

[11] Fac-Beneda J.: Charakterystyka hydrologiczna jeziora Druzno, [w:] Cz. Nitecki (red.), Jezioro Druzno - Monografia Przyrodnicza, Wyd. Mantis, Olsztyn 2013, s. 15-31.

[12] Krajewski Z. (red.): Raport o stanie środowiska województwa warmińsko-mazurskiego w 2004 roku, Biblioteka Monitoringu Środowiska, Olsztyn 2005.

[13] Budzyńska D. (red.): Raport o stanie środowiska województwa warmińskomazurskiego w 2007 roku, Biblioteka Monitoringu Środowiska, Olsztyn 2008.

[14] Budzyńska D. (red.): Raport o stanie środowiska województwa warmińsko-mazurskiego w 2012 roku, Biblioteka Monitoringu Środowiska, Olsztyn 2013.

[15] Drwal J., Cieśliński R.: Ocena możliwości wptywu zanieczyszczeń punktowych i obszarowych oraz wlewów odmorskich na jakość wód jeziora Druzno, [w:] W. Lange i D. Borowiak, Zagrożenia degradacyjne a ochrona jezior, Wyd. DJ, Gdańsk 1998, s. 93-105.

[16] Bogdanowicz R.: Transport biogenów $w$ druzneńskim systemie hydrograficznym, [w:] J. Drwal (red.), Wody delty Wisły, GTN, Gdańsk 2002, s. 65-82.

[17] Bogdanowicz R.: Hydrologiczne uwarunkowania transportu wybranych zwiazków azotu i fosforu Odra i Wista oraz rzekami Przymorza do Battyku, Wyd. UG, Gdańsk 2004.

[18] Przybylski M., Pranga J., Łyko M., Sawicka D.: Wpływ Zakładów SERY ICC PASŁĘK na ekosystemy wodne potoku Brzezinka Rzeki Waska oraz formy ochrony przyrody J. Druzno, Biuro Projektów Środowiskowych, Gdańsk (maszynopis) 2015.

[19] Pieniążek A., Felinczak E., Felinczak M.: Przebudowa koryta rzeki Waska - DOKUMENTACJA PROJEKTOWA. Operat wodno-prawny, Biuro Projektowo - Consultingowe HydroEco, Gdańsk (maszynopis) 2011.

[20] Wojewódzki Inspektorat Ochrony Środowiska w Olsztynie Delegatura w Elblągu sprawozdanie $\mathrm{nr}$ 173/2014/PEI z dnia 03.06.2014 (maszynopis).

[21] Kwidziński R., Mizera G.: Obliczenia masy amoniaku uwolnionego podczas wycieku do wody lodowej, Instytut Maszyn Przepływowych im. Roberta Szewalskiego PAN, Gdańsk (maszynopis) 2015.

[22] Francis-Floyd R., Watson C., Petty D., Pouder D.B.: Ammonia in Aquatic Systems, Department of Fisheries and Aquatic Sciences, Florida Cooperative Extension Service, Institute of Food and Agricultural Sciences, University of Florida 1990. 
[23] Zima P.: Modelowanie procesu transportu zanieczyszczeń w rzece Wąskiej pod kątem zrzutu ścieków z zakładu mleczarskiego Sery ICC Pastęk Sp. z o.o. w Pastęku, Gdańsk (maszynopis) 2014a.

[24] Zima P.: Modelowanie procesu transportu zanieczyszczeń w rzece Waskiej pod kątem niekontrolowanego zrzutu amoniaku $w$ dniu 19 maja 2014r. z zakładu mleczarskiego Sery ICC Pastęk Sp. z o.o. w Pastęku, Gdańsk (maszynopis) 2014b.

[25] Marivoet J.L., van Craenenbroeck W.: Longitudinal dispersion in shipcanals, Journal of Hydraulic Research, vol. 24, no 2, 1986, pp. 123-132.

[26] Leonard B.P.: A Stable and Accurate convective Modelling Procedure Based on Quadratic Upstream Interpolation, Computer Methods in Applied Mechanics and Engineering, vol. 19, 1979, pp. 59-98.

[27] Leonard B.P.: The ULTIMATE Conservative Difference Scheme Applied to Unsteady One-Dimensional Advection, Computer Methods in Applied Mechanics and Engineering, vol. 88, 1991, pp. 17-74.

[28] HEC-RAS River Analysis System: Hydraulic Reference Manual, US Army Corps of Engineers, Davis 1997.

[29] Krukowski M.: Porównanie wartości wspótczynników dyspersji zanieczyszczeń pasywnych wyznaczonych z pomiarów na rzece Wkrze z obliczeniami zależności empirycznych, Przegląd Naukowy Inżynieria i Kształtowanie Środowiska, nr 1, z. 24, 2002, s. 228-239.

[30] Dojlido J.: Chemia wód powierzchniowych, Wyd. Ekonomia i Środowisko, Białystok 1995.

[31] Groenewag J., Sellner B., Tappe W.: Ammonia oxidation in nitrosomonas at $\mathrm{NH}_{3}$ concentrations near $K_{m}$ : Effects of $\mathrm{pH}$ and temperature, Water Research, vol. 28, no 12,1994 , pp. 2561-2566.

\section{HYDROCHEMICAL ASSESSMENT OF ECOLOGICAL DISASTER ON THE LAKE DRUZNO AND RIVER WĄSKA IN 2014}

\section{S u m m a r y}

The aim of the study is to assess hydrochemical impact of pollution, which fall into the days 19-20.05. 2014 to the river Wąska and Lake Druzno and determine is it ecological disaster. With Lake Druzno has landed this time, about 2 tons of dead fish, including species that are protected, and small aquatic organisms such as snails and clams. State institutions have recognized that the cause of this state of affairs was the flow of pollution from the plant Sery ICC Pasłęk. The main work consisted of the query source materials and the field and laboratory work. In 2015, we have been sampling water from the river Wąska and Lake Druzno, which were then analyzed for determining the concentrations of indicators such as nitrates, nitrites, ammonia. Also made modeling the transport of pollutants in the river Wąska using HEC-RAS. As a result, it was found that contaminants have entered the narrow river were local in nature and in no case cannot talk about the ecological disaster in the region.

Keywords: pollution, quality, ammonia, transportation 